There were certain books in the former Soviet Union and eastern Europe that aroused Katia's deep concern: "trophy" books from the warzones of Europe. Crammed into decommissioned churches and shelved in library book stacks, many in extremely poor condition, these unacknowledged collections, including everything from cookbooks to Gutenberg Bibles, had been hidden, ignored, and forgotten. Katia took the trophy books up as one of her causes and worked with partners in Germany and other countries to identify collections, make information available to everyone, and, when possible, return books to their rightful owners. A further project was bringing to Russia publications by émigré writers who had left the country during the Soviet era and whose books had been banned. For instance, she worked with the YMCA Press in France, publisher of many notable émigrés, to bring books to libraries around the former Soviet Union-and leave them there.

Another of Katia's causes was tolerance. She mounted dozens of exhibitions on difficult, troubling topics-antisemitism in Russia and the destruction of Jews on Soviet soil during World War II, the wars in Chechnia, censorship-and took them on the road to libraries all over the country, accompanied by books, lectures, and seminars. I once asked her if she was ever afraid of reprisals. "A little," she said, and shrugged. "One must go on."

Finally, I hope historians will record the far-reaching and profound effects of George Soros's generous efforts in Russia, beginning in the chaotic 1990s, in which Katia played a leading role. She was president of one of Soros's largest programs, the Open Society Foundation in Russia, which gave hundreds of millions of dollars for establishing Internet access all over the country and for textbooks for schools and institutes for higher education, health, and tolerance, and, last but not least, libraries and cultural centers. These projects established a pattern of matching funds from national, regional, and local governments and foundations to guarantee sustainability.

Despite her illness, Katia continued to travel internationally and within Russia, working tirelessly on various projects. In her last year, we spoke nearly every day by phone. "Where are you today?" I would ask, and she would name a European country or a city on the other side of Russia, many time zones removed from Moscow. "I arrived this morning, and I'll fly back on Tuesday. Everything's going splendidly. Call again tomorrow."

MARIANNA TAX CHOLDIN

University of Illinois, Urbana-Champaign

September 2015

\title{
Andrei Konstantinovich Sokolov, 1941-2015
}

Andrei Konstantinovich Sokolov was an accomplished social historian of international stature and the leading historian of the Soviet working class of the prewar period. The most productive member of the remarkable cohort of V. Z. Drobizhev's students who became leaders of the late Soviet historical profession, Sokolov established himself as a leading figure in Soviet history and a major influence on those he trained.

Andrei came from the working class he studied. Born into privation during World War II (which killed his father), he spent hard childhood years in small Vladimir region towns like Iur'ev-Pol'skii and Kineshma. From age seventeen, he worked making bread, cutting timber, and stoking fires in various factories. A true vydvizhenets promoted from the proletariat, Andrei was identified by Soviet authorities as a worker with intellectual promise. Selected to attend Moscow State University in 1963, he ex- 
celled in history and eventually taught there. He began his career in 1987 in the Institute of Russian History of the Academy of Sciences, where he began to train the next generation of social historians who are now among the most visible in Russia.

Along with other students of Drobizhev, Andrei refused to be constrained by narrow, prescribed Soviet interpretive cant. Because the group specialized in the application of mathematical methods to social history, they were able to maneuver more freely within Soviet constraints. Like his classmates, Andrei did not have separate "official" and "personal" sides. Even in those late Soviet transition days, and unlike many who shied away from contact with foreigners, he was open to everybody and ready to consider all points of view. He took (or ignored) risks that frightened others. When it was still unsafe to speak too freely with one's office door open, Andrei would tell us foreigners about the "Lenin sandwich," whereby one cited Vladimir Lenin at the beginning and at the end, but in the middle one could say what one wanted because the censors did not understand numbers.

While never losing his love of and incredible proficiency with statistics, he moved beyond the limitations of mathematical history. He was the author of 15 books and more than 150 articles on subjects ranging from the history of the Soviet working class to economic history to source methodology to the Soviet military-industrial complex. Few historians, here or there, have such versatility without being dilettantes. Whatever the subject, Andrei tackled it with solid research, with seriousness of purpose, and without fanfare, which he derided as unnecessary shum.

In the Gorbachev period, unlike many of his colleagues, Andrei avoided declarations about how perestroika was a promising neo-NEP, even though he had forgotten more about NEP society than many of his colleagues ever knew in the first place. Uninterested in the spotlight, Andrei instead used the newly open possibilities to publish even more prodigiously and to bring serious history to the Russian public. At a time when new Soviet history textbooks of wildly varying quality appeared almost every week, his still-relevant Kurs sovetskoi istorii, 1917-1940 (A Course on Soviet History, 1917-1940 [Vysshaia shkola, 1999]) became a bestseller. He also labored behind the scenes, devoting considerable energy to such efforts as securing publication of western scholars' work and campaigning to prevent the destruction of "extra" archival documents, to name only a few. He was unique in contributing so much with so little showy self-promotion.

Andrei saw the Soviet historical profession, and research in general, as an international collegial effort. One of the first Soviet scholars to visit the United States on an academic exchange in the 1960s, he valued his new connections and nurtured them into lifelong friendships and collaborations. Unlike many of his contemporaries, he studied western historiography and, as head of the Institute of Russian History's istochnikovedenie group, he made that changing historiography available to Russian scholars, often in a quite critical but always informed way.

In the early days of perestroika, when archives were hesitantly starting to open to foreigners, he went out of his way to share his vast knowledge of the ins and outs of the collections, the fondy in which to search, the procedures for obtaining permission, and many other things. Because personal connections were and are so important in Russia, he paved our way into the archives with his prestige by introducing us personally to key officials.

When state support of education plummeted during the terrible '90s, Andrei survived, like many of his fellow academics, by assuming three, four, and even more positions -in the Institute of Russian History's administration, at MGU, and at RGGU-yet still found time for collaborative projects with Russian and foreign scholars. Whether collaborating with us on a book or to create a computer lab, Andrei was 
a delight to work with. He was that rare person who combined brilliance and seriousness of purpose with humor and humanity.

Visits to his afternoon office hours at the institute often attracted those from neighboring offices and became wonderful, far-ranging discussions of books and ideas, often encouraged by vodka and extending into snowy evenings. Dinners at his home were similarly relaxed, and even in the hardest times of defitsit, he and his wife, Natasha, managed to load their table with delicacies they could not afford. His good cheer and the value he placed on friendship extended to his trips to the United States. Rather than hunt for scarce western goods to take home, Andrei would rather attend a Siegelbaum son's soccer game or giggle as he played endless games of fetch with Arch Getty's beagle, Earl.

Time with him and Natasha was always a treat, full of heart-to-heart conversations with no subjects excluded. As his health began to decline, Natasha would forbid vodka at the table, limiting Andrei to a single beer. In that way he had, Andrei would complain with good nature, frown while smiling, and then do exactly what Natasha told him to do. We think she was the only person on the planet whom he obeyed, although he did sometimes sneak around to enjoy a forbidden cigarette.

Russian studies is poorer without Andrei Konstantinovich, and our lives are smaller and sadder. We will miss him tremendously.

\author{
J. ARCH GETTY \\ University of California, Los Angeles \\ LEWIS SIEGELBAUM \\ Michigan State University \\ October 2015
}

\title{
Charles E. Townsend, 1932-2015
}

Charles E. Townsend, a legendary figure in Slavic linguistics, died peacefully at his home on June 7, 2015, surrounded by his family members. He is survived by his wife, Janet, three daughters-Erica, Sylvia, and Louise-five grandchildren, and many grateful colleagues and students who fondly addressed him as "Charlie."

Townsend was born in 1932 and grew up in Vermont and New York. After graduating first in his class from the Trinity School in Manhattan, Townsend pursued an all-Ivy academic career. He graduated magna cum laude in German from Yale and obtained his $\mathrm{PhD}$ in Slavic linguistics under the tutelage of Roman Jakobson and Horace Lunt at Harvard, where he also served as an assistant professor for four years. Townsend then spent four decades at Princeton, most of that time as chair of the Department of Slavic Languages and Literatures. He also taught intensive Russian courses at the Indiana University Slavic Summer Workshop in 1972-81.

Townsend's achievements were remarkable in their quantity, quality, and scope. Though his primary focus was on Russian and Czech, he also taught courses in Polish, Serbo-Croatian, Bulgarian, Old Church Slavonic, and comparative Slavic linguistics. Several of Townsend's books have become classics, appreciated by generations of Slavists, among them Russian Word-Formation (McGraw-Hill, 1968; reprinted by Slavica in 1975), Continuing with Russian (McGraw-Hill, 1970), Czech through Russian (Slavica, 1981; revised and expanded in 2000), A Description of Spoken Prague Czech (Slavica, 1990), and Common and Comparative Slavic: Phonology and Inflection with Special Attention to Russian, Polish, Czech, Serbo-Croatian, Bulgarian (Slavica, 1996; 